\title{
Geothelphusa boreas, a new montane freshwater crab (Crustacea: Potamidae: Geothelphusa) from northeastern Taiwan, and the identity of G. hirsuta Tan \& Liu, 1998
}

\author{
JHY-YUN SHY ${ }^{1}$, HSI-TE SHIH ${ }^{2 *} \&$ JEAN-JAY MAO ${ }^{3}$ \\ ${ }^{1}$ Department of Aquaculture, National Penghu University, 300 Liuhe Road, Magong City, Penghu 880, Taiwan. \\ (1) https://orcid.org/0000-0003-3998-4046 \\ ${ }^{2}$ Department of Life Science and Research Center for Global Change Biology, National Chung Hsing University, 250 Kuo Kuang \\ Road, Taichung 402, Taiwan. \\ (1) https://orcid.org/0000-0003-1317-8783 \\ ${ }^{3}$ Department of Forestry and Natural Resources, National Ilan University, 1, Sec. 1, Shen-Lung Road, Yilan 260, Taiwan. \\ (i) https://orcid.org/0000-0002-8327-9582 \\ ${ }^{*}$ Corresponding author:
}

\begin{abstract}
A new freshwater crab is described from the montane area in northeastern Taiwan based on morphological and molecular evidence. Geothelphusa boreas sp. nov., from the Fushan Botanical Garden situated around New Taipei City and Yilan County, is distinct from similar congeners by the structure of the male first gonopod and the proportions of the male thoracic sternites. In addition, after comparing the holotypes of G. takuan and G. hirsuta Tan \& Liu, 1998, no substantial difference could be found. Molecular evidence from mitochondrial cytochrome oxidase subunit I also supports the recognition of the new species and the conspecificity of G. hirsuta with G. takuan.
\end{abstract}

Key words: Potamidae, freshwater crab, new species, Geothelphusa boreas, G. hirsuta, G. takuan, Taiwan, mitochondrial DNA, cytochrome oxidase subunit I

\section{Introduction}

While many taxa of freshwater crabs have been described from China after the review in Shih \& $\mathrm{Ng}$ (2011) (e.g. KL Chu et al. 2017, 2018a, b; Huang et al. 2014, 2016, 2017a, b, 2018, 2020a, b, c; Huang 2018; Wang et al. 2019; Mao \& Huang 2020; PF Wang et al. 2020), fewer have been reported from the East Asian arc (Taiwan, the Ryukyus and main islands of Japan) (Suzuki \& Kawai 2011; Shy et al. 2014, 2020; Ng et al. 2017), although some are still awaiting description (Shy et al. 2020: p. x). Geothelphusa Stimpson, 1858 is the second largest genus in the Potamidae (Ng et al. 2008; Shih \& Ng 2011) and is endemic to the East Asian arc. There are 57 recognized species, with 39 species in Taiwan, 15 in the Ryukyus and three in the main islands of Japan (Shih \& Ng 2011; Suzuki \& Kawai 2011; Shy et al. 2014, 2020). While most Taiwanese Geothelphusa species live in low to middle altitudes, seven species, viz. G. cilan Shy, Shih \& Mao, 2014; G. eurysoma Shy, Ng \& Yu, 1994; G. gracilipes Shy, Ng \& Yu, 1994; G. haituan Chen, Hsu \& Cheng, 2007; G. hirsuta Tan \& Liu, 1998; G. monticola Shy, Ng \& Yu, 1994; and G. takuan Shy, Ng \& Yu, 1994, inhabit the montane region at altitudes higher than $1000 \mathrm{~m}$ a.s.l. (Shy \& Lee 2009; Shy et al. 2014). Molecular evidence has supported most of these montane species having a close phylogenetic relationship (Ng et al. 2010; Shih et al. 2010, 2011; Shy et al. 2014).

In the study of Shih et al. (2011), the "G. sp. 2" has been published as G. cilan, while the "G. sp. 1", collected from the Fushan Botanical Garden, located in the mountainous area of New Taipei City and Yilan County, northeastern Taiwan has remained undescribed. Additional surveys around this region confirmed a wider distribution of this species. The structure of the male first gonopod and the proportions of the male thoracic sternites are different from other similar species, and it is herein described as new. 
In addition, there is a subclade composed of G. takuan, G. hirsuta and G. cf. hirsuta in Shih et al. (2011). After reexamining the type specimens of $G$. takuan and $G$. hirsuta, we now believe that $G$. hirsuta is a junior synonym of G. takuan. No substantial morphological difference could be found and they are also genetically almost identical.

\section{Material and methods}

Specimens collected by hands, traps (with bait) or pitfalls (without bait) from northeastern Taiwan (Table 1; Fig. 1) were preserved in 70\% 95\% ethanol and deposited in the Zoological Collections of the Department of Life Science, National Chung Hsing University, Taichung, Taiwan (NCHUZOOL). Other specimens deposited in the Department of Environmental Biology and Fisheries Science, National Taiwan Ocean University, Keelung, Taiwan (NTOU), the National Taiwan Museum (TMCD), and the Zoological Reference Collection of the Lee Kong Chian Natural History Museum, National University of Singapore, Singapore (ZRC), were examined. Specimens were illustrated with the help of a drawing tube attached to a stereomicroscope. The terminology used primarily follows that in $\mathrm{Ng}$ (1988), Shy et al. (1994) and Davie et al. (2015). Measurements provided are of the maximum carapace width (CW) and carapace length (CL) in millimeters. The following abbreviations are used: G1 for the male first gonopod and G2 for the male second gonopod.

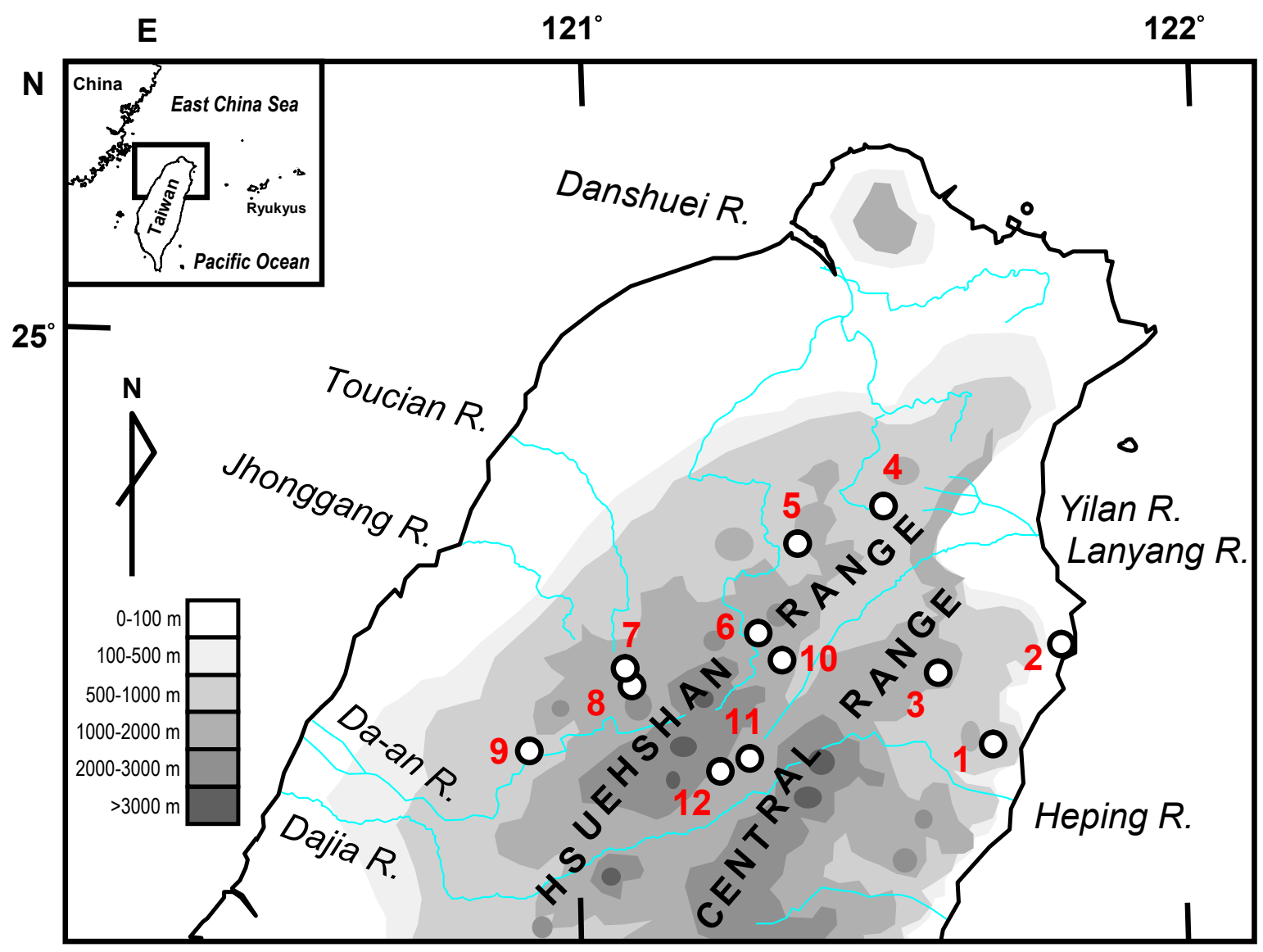

FIGURE 1. Collection sites (empty circles) for the Geothelphusa species from northern Taiwan. For locality names, see Table 1. R. = river.

Genomic DNA was isolated from the leg muscle tissue by using the GeneMark tissue and cell genomic DNA purification kit (Taichung, Taiwan). A portion of the COI gene was amplified with PCR using the primers LCO1490, HCO2198 (Folmer et al. 1994), and COL14 (Roman \& Palumbi 2004; Schubart 2009). The PCR conditions for the above primers were denaturation for $50 \mathrm{~s}$ at $94^{\circ} \mathrm{C}$, annealing for $70 \mathrm{~s}$ at $45-47^{\circ} \mathrm{C}$, and extension for $60 \mathrm{~s}$ at $72^{\circ} \mathrm{C}$ (40 cycles), followed by extension for $10 \mathrm{~min}$ at $72^{\circ} \mathrm{C}$. Sequences were obtained by automated sequencing (Applied Biosystems 3730) and were aligned manually, after verification with the complementary strand. Sequences of different haplotypes were deposited in NCBI GenBank (accession numbers in Table 1), with other sequences of closely related species (Shih et al. 2010, 2011; Shy et al. 2014) (Table 1). 
TABLE 1. Specimens and COI haplotypes of Geothelphusa collected from the montane areas of northern Taiwan. The numbers within brackets following localities correspond to those in Fig. 1. ${ }^{\text {a }}$ Fushan Botanical Garden is located between Wulai, New Taipei City and Yuanshan, Yilan County; ${ }^{\mathrm{b}}$ Sequences are shorter and not included for further analyses (see "DNA analyses and discussion").

\begin{tabular}{|c|c|c|c|c|c|}
\hline species & locality in Taiwan & $\begin{array}{l}\text { catalogue no. of } \\
\text { NCHUZOOL } \\
\text { (unless indicated) }\end{array}$ & $\begin{array}{l}\text { sample } \\
\text { size }\end{array}$ & $\begin{array}{l}\text { haplotype } \\
\text { of COI }\end{array}$ & $\begin{array}{l}\text { accession } \\
\text { no. }\end{array}$ \\
\hline G. boreas & Fushan Botanical Garden [4] ${ }^{\mathrm{a}}$ & 13429 & 2 & Gbr1 & AB625744 \\
\hline \multirow[t]{5}{*}{ sp. nov. } & & 13429 & 2 & Gbr2 & AB625745 \\
\hline & Yilan: Dakeng Bridge, Suao [2] & 13616 & 3 & Gbr3 & MZ673391 \\
\hline & & 13616 & 1 & Gbr4 & MZ673392 \\
\hline & Yilan: Shenmihu, Nan-ao [1] & 16436 & 2 & Gbr5 & MZ673393 \\
\hline & Yilan: Tongshan, Nan-ao [3] & 14998 & 2 & Gbr6 & MZ673394 \\
\hline \multirow[t]{9}{*}{ G. takuan } & Taoyuan: Daguanshan (= Lalashan), Fusing [5] & 13285 & 1 & Gtk1 & AB625747 \\
\hline & & 13285 & 1 & Gtk2 & MZ673395 \\
\hline & & 13285 & 1 & Gtk3 & AB535480 \\
\hline & & 16435 & 1 & Gtk3 & AB535480 \\
\hline & & 16435 & 1 & Gtk4 & MZ673396 \\
\hline & Hsinchu County: Smangus, Jianshih [6] & 17041 & 4 & $\begin{array}{l}\text { Gtk5, } \\
\text { Gtk6, } \\
\text { Gtk7 }\end{array}$ & $\begin{array}{l}\text { MZ854144, } \\
\text { MZ854145, } \\
\text { MZ854146 }\end{array}$ \\
\hline & Hsinchu County: Syueba Farm, Wufeng [7] & 13432 & 2 & Gtk8 & MZ673397 \\
\hline & & 13432 & 1 & $-^{\mathrm{b}}$ & AB625750 \\
\hline & Miaoli: Sihmasian Forest Road, Tai-an [9] & 13431 & 1 & Gtk9 & AB625749 \\
\hline (G. hirsuta) & Miaoli: Guanwu, Tai-an [8] & $\begin{array}{l}\text { TMCD } 3285 \\
\text { (holotype), } 3292 \\
\text { (paratype), ZRC } \\
\text { (paratype) }\end{array}$ & 3 & Gtk10 & AB625748 \\
\hline \multirow[t]{5}{*}{ G. cilan } & Hsinchu County: Cilanshan, Jianshih [10] & 13617 (holotype) & 1 & GcL1 & AB625746 \\
\hline & & 13430 & 4 & GcL1 & AB625746 \\
\hline & & 13430 & 1 & $-^{\mathrm{b}}$ & MZ673398 \\
\hline & & 13618 & 2 & GcL2 & LC002663 \\
\hline & & 13619 & 1 & GcL3 & LC002664 \\
\hline \multirow[t]{8}{*}{ G. monticola } & Yilan: upper reach of Lanyang R. [11] & 13287 & 2 & Gmt1 & MZ673399 \\
\hline & & 13287 & 1 & $-^{\mathrm{b}}$ & AB535481 \\
\hline & Yilan: Siyuanyakou, Datong [11] & 13288 & 2 & Gmt1 & MZ673400 \\
\hline & & 13288 & 1 & $-^{\mathrm{b}}$ & AB535481 \\
\hline & Taichung: Siaoyako, Heping [12] & $\begin{array}{l}\text { NTOU F10204 } \\
\text { (holotype) }\end{array}$ & 1 & $-^{\mathrm{b}}$ & AB535481 \\
\hline & Taichung: Cijiawan R., Heping [12] & 13286 & 1 & $-^{\mathrm{b}}$ & AB535481 \\
\hline & & 13621 & 1 & Gmt2 & MZ673401 \\
\hline & & 13433 & 1 & $-^{\mathrm{b}}$ & AB625751 \\
\hline \multicolumn{6}{|l|}{ outgroups } \\
\hline G. eurysoma & Taichung: Dasyueshan Forest Road, Heping & 13622 & 1 & & LC002665 \\
\hline G. gracilipes & Hualien: Lyushuei, Shioulin & TMCD & 1 & & AB535479 \\
\hline G. nanao & Yilan: Jinyang, Nan-ao & $\begin{array}{l}\text { NTOU F10195 } \\
\text { (holotype) }\end{array}$ & 1 & & AB535472 \\
\hline G. tali & Yilan: Dali & $\begin{array}{l}\text { NTOU F10187 } \\
\text { (holotype) }\end{array}$ & 1 & & MZ673402 \\
\hline
\end{tabular}


The best-fitting model for sequence evolution was determined by PartitionFinder (vers. 2.1.1, Lanfear et al. 2017) and was selected by the Bayesian information criterion (BIC). The obtained best model ( $\mathrm{HKY}+\mathrm{G})$ was subsequently used for a Bayesian inference (BI) analysis. The BI analysis was performed with MrBayes (vers. 3.2.3, Ronquist et al. 2012). Phylogenetic analyses were run with four chains for 10 million generations and four independent runs, with trees sampled every 1000 generations. The convergence of chains was determined by the average standard deviation of split frequency values below the recommended 0.01 (Ronquist et al. 2020), and the first 1000 trees were accordingly discarded as burnin. The minimum evolution (ME) tree was constructed on MEGA (vers. 10.0.5; Kumar et al. 2018 ) with the gamma correction $(=0.934)$ obtained from jModeltest (vers. 2.1.4; Darriba et al. 2012; selected by the Akaike information criterion (AIC) and the Kimura (1980) two-parameter model (CNI level $=2$, initial tree $=\mathrm{NJ}$, and maximum number of trees to retain $=1$ ) and 2,000 replicates. The pairwise estimates of Kimura (1980) two-parameter (K2P) model distance for inter- and intraspecific genetic diversities were calculated using MEGA.

\section{Results}

\section{Systematic account}

Family Potamidae Ortmann, 1896

Subfamily Potamiscinae Ortmann, 1896 (sensu Yeo \& Ng 2003)

Genus Geothelphusa Stimpson, 1858

Geothelphusa boreas sp. nov.

(Figs. 4-5)

urn:lsid:zoobank.org:act:6DC2B082-D052-49B3-B243-941D38306477

Geothelphusa sp. 1. - Shih et al. 2011: 461.

Material examined. Holotype: 1 § $(21.2 \times 16.4 \mathrm{~mm})(\mathrm{NCHUZOOL} 13615)$, Hapen River, head branch of Dans-

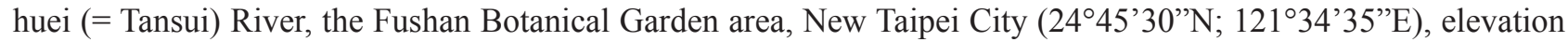
of $740 \mathrm{~m}$, coll. H.-T. Shih, 16 Feb. 1994. Paratypes: 3 ठิ $\widehat{\partial}(15.7 \times 12.4-19.0 \times 14.7 \mathrm{~mm}), 2$ 우 $(15.3 \times 12.1$, $17.1 \times 13.1 \mathrm{~mm})($ NCHUZOOL 13429), $1 \widehat{\delta}(16.2 \times 13.2 \mathrm{~mm})($ ZRC 2021.0648); same data as holotype. Others: 7 ठิ $\widehat{\partial}(11.4 \times 9.2-15.3 \times 12.2 \mathrm{~mm}), 1$ q $(16.6 \times 12.9 \mathrm{~mm})($ NCHUZOOL 13616), Dakeng Bridge, Suao, Yilan

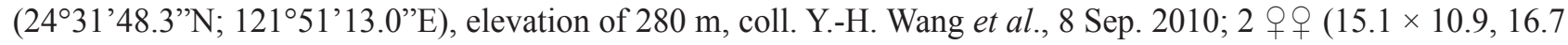
$\times 12.8 \mathrm{~mm})(\mathrm{NCHUZOOL} 16436)$, around the lake of Shenmihu, Nan-ao, Yilan (24⒉'43.9"N; $\left.121^{\circ} 44^{\prime} 58.7^{\prime \prime} \mathrm{E}\right)$, elevation of $1100 \mathrm{~m}$, coll. J.-J. Mao, 10 Mar. 2018; 1 § $(12.7 \times 9.7 \mathrm{~mm}), 1$ q $(13.9 \times 10.5 \mathrm{~mm})($ NCHUZOOL 14998), 1 q $(13.5 \times 10.3 \mathrm{~mm})(\mathrm{ZRC} 2021.0649)$, Tongshan, Nan-ao, Yilan $\left(24^{\circ} 30^{\prime} 15.5^{\prime \prime} \mathrm{N} ; 1^{\circ} 1^{\circ} 37^{\prime} 41.8^{\prime \prime} \mathrm{E}-24^{\circ} 30^{\prime} 03.5^{\prime \prime} \mathrm{N}\right.$; 121 $38^{\prime} 10.2^{\prime \prime E}$ ), elevation of 1735-1880 m, coll. J.-J. Mao, 26 Sep. 2009.

Comparative material. Geothelphusa takuan Shy, Ng \& Yu, 1994: see "Material examined" under Geothelphusa takuan; Geothelphusa tali Shy, Ng \& Yu, 1994: 1 holotype male (NTOU F10187), Dali (= Tali), Yilan Co., Taiwan, coll. J.-Y. Shy \& W.-L. Tsay, 4 Apr. 1993.

Diagnosis. Carapace length, width 1.7-, 2.3-times carapace height, respectively. Anterolateral margins distinct, lined with inconspicuous granules, without epibranchial tooth. Subterminal segment of G1 (Fig. 3A-C) curving inwards, outer proximal margin without tooth; terminal segment slightly curving outwards to almost straight; total length of G1 5.8 times terminal segment.

Description. Carapace (Fig. 2A, B) swollen longitudinally, transversely; dorsal surface smooth, glabrous, with fine pits. Carapace length, width 1.7-, 2.3-times carapace height, respectively. Frontal margin slightly dived into 2 lobes, without tooth. Postorbital cristae distinct, supraorbital margin smooth, without granules; infraorbital margin smooth to almost smooth, lined with inconspicuous granules. External orbital angles stout, external orbital regions concave. Anterolateral margins distinct, lined with inconspicuous granules, without epibranchial tooth. Postorbital cristae faint, smooth. Gastric, cardiac, intestinal regions smooth. H-shaped groove distinct. Tip of medium lobe of epistome stout. Distance between tip of sternopleonal cavity (Fig. 2C) and anterior margin of thoracic sternite 3 about 2.2 times length of thoracic sternites 1 and 2 . 


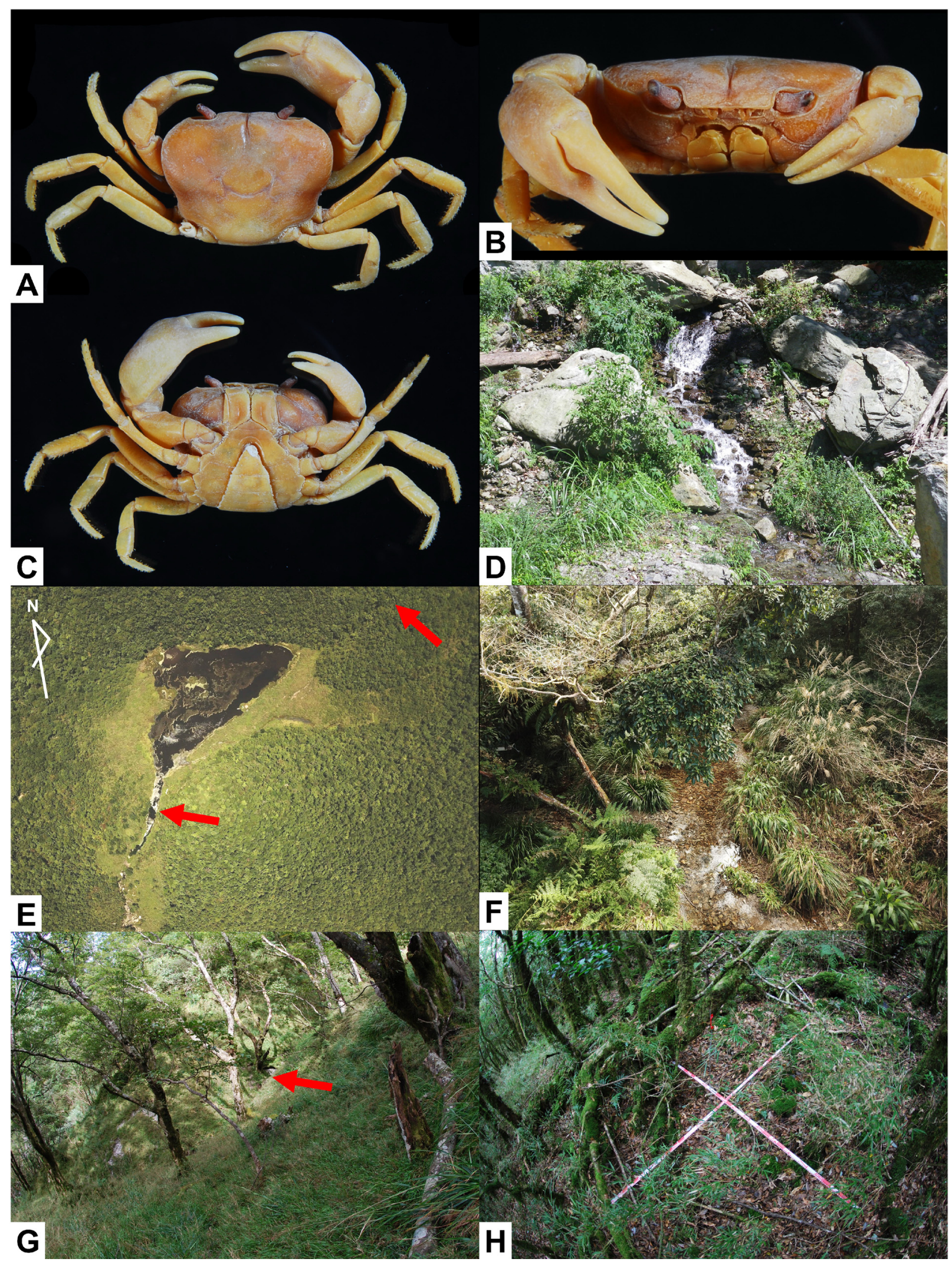

FIGURE 2. Geothelphusa boreas sp. nov. A, B, C, dorsal, frontal and ventral views of the holotype (NCHUZOOL 13615); D, habitat in Dakeng Bridge, Suao, Yilan; E, F, habitat in Shenmihu, Nan-ao, Yilan; G, H, habitat in Tongshan, Nan-ao, Yilan. The arrows in $\mathrm{E}$ and $\mathrm{G}$ indicated the localities with crabs observed. The two rulers in $\mathrm{H}$ were used for a separate ecological study of the habitat. 

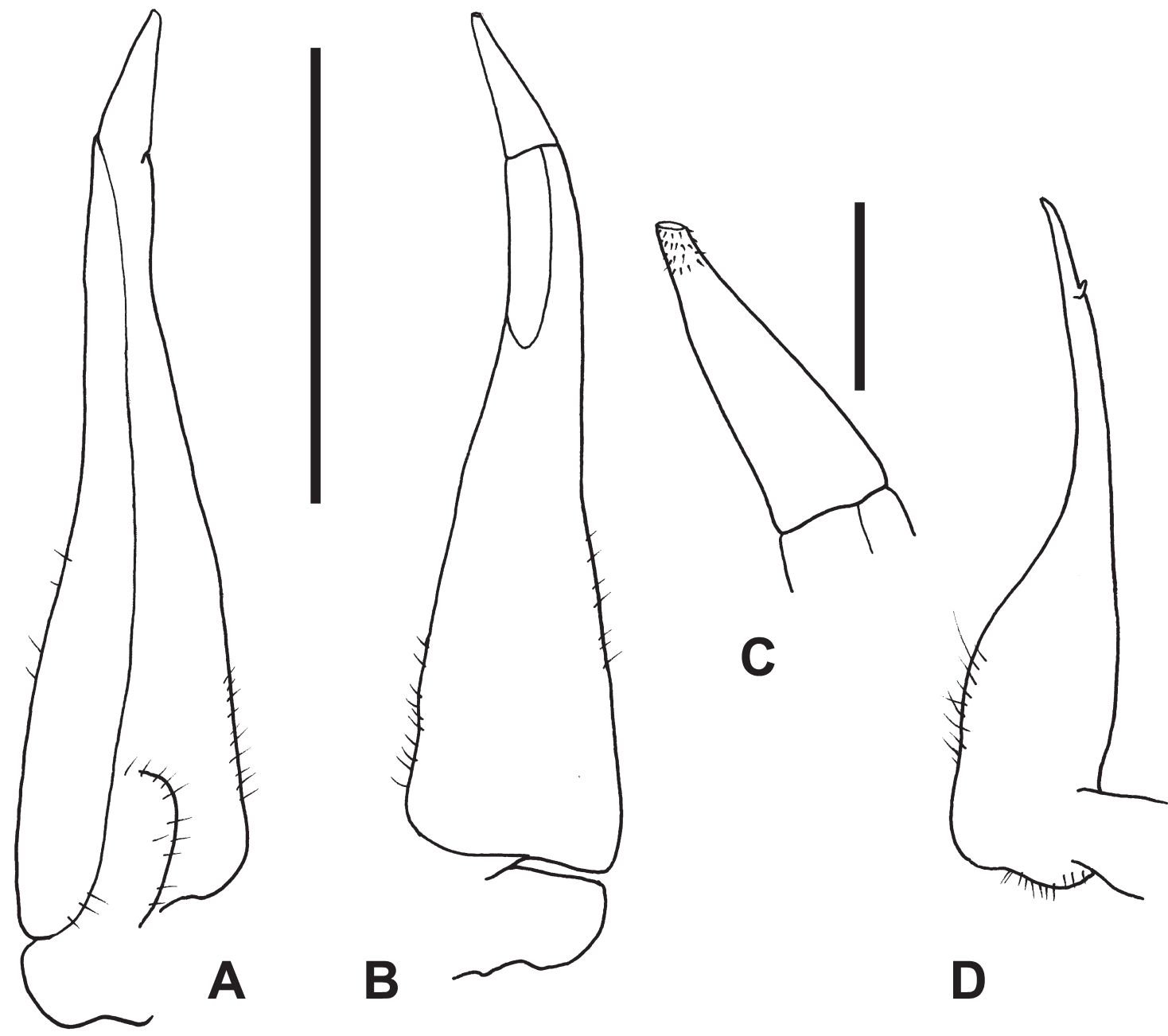

FIGURE 3. Male right $\mathrm{G} 1$ and $\mathrm{G} 2$ of Geothelphusa boreas sp. nov. (holotype, NCHUZOOL 13615). A, D, ventral view of G1; $\mathrm{B}$, dorsal view of $\mathrm{G} 1$; C, terminal segment of $\mathrm{G} 1$; D, ventral view of $\mathrm{G} 2$. Scale $=2.5 \mathrm{~mm}$ for $\mathrm{A}, \mathrm{B}, \mathrm{D}$; scale $=0.5 \mathrm{~mm}$ for $\mathrm{C}$.

Chelipeds (Fig. 2A, B) of adult male unequal, fingers of larger chela forming obliquely triangular gape when closed. Ambulatory legs (Fig. 2A, C) smooth, dorsal, ventral margins of dactyli with 2 rows of small spines, respectively. Second leg about 1.8 carapace length. Telson bell-shaped, moderately short, width about 1.5 length.

Subterminal segment of G1 (Fig. 3A-C) curving inwards, outer proximal margin without tooth in most specimen, some smaller specimen $(<13.8 \mathrm{~mm})$ with low tooth, inner proximal margin slightly dilated; terminal segment slightly curving outwards to almost straight; total length of G1 5.8 times terminal segment; length of synovial membrane about 4.6 times maximum width. Outer proximal margin of basal segment of G2 (Fig. 3D) dilated, showing a single lobe; distal segment short, about 0.16 times total length.

Etymology. The species is derived from the Greek "boreas" (for north), alluding to the northernmost distribution of this species in the Central Range.

Ecological notes. The specimens were collected from the montane area with an elevation of $740 \mathrm{~m}$ (the Fushan Botanical Garden area) to $1100 \mathrm{~m}$ (Shenmihu) and about $1800 \mathrm{~m}$ (Tonghsan), but also extended to the coastal cliff area of Suao (elevation of $280 \mathrm{~m}$ ) (Fig. 1). The distributional range of this species covers an area of $45 \mathrm{~km}$ (from Fushan to Shenmihu; Fig. 1). There was running water in most habitats (Fig. 2D-F), but some crabs were more semiterrestrial, hiding under fallen leaves with only some seepage in Tongshan (Fig. 2G, H). Other species sympatric with this species include members of the G. eucrinodonta species complex, G. tali and G. ilan Shy, Ng \& Yu, 1994 in Fushan area (Shih et al. 2010). In the higher altitude (Tongshan and Shenmihu), the habitats of the new species are near the Fagus hayatae (Taiwan beech) forest (Fig. 2E-H), with the mean (and standard deviation) water temperature $17.66 \pm 2.12{ }^{\circ} \mathrm{C}$ (April 2018) and $23.25 \pm 1.78{ }^{\circ} \mathrm{C}$ (May to September 2018), $\mathrm{pH} 7.4 \pm 0.3$ (April to October 2018) and dissolved oxygen $8.7 \pm 0.9 \mathrm{mg} / \mathrm{L}$ (April to October 2018) in Shenmihu (Fig. 2F). 
Remarks. Geothelphusa boreas sp. nov. is morphologically most similar to G. takuan and G. tali which occurs in adjacent regions in northern Taiwan. The G1 structures remain the best way to separate them. The subterminal segment of the G1 of G. tali is straight (Shy et al. 2020: fig. 124), while those of present new species and G. takuan are distinctly curved inwards (Figs. 3, 4A, B; Shy et al. 2020: fig. 121). In addition, the G1 subterminal segment in G. takuan has a distinct tooth on the outer proximal margin (Fig. 4A), while in G. boreas, there is usually no tooth present on the structure (or at most with a faint knob in some small individuals) (Fig. 3A). The distance between the tip of the sternopleonal cavity and the anterior margin of thoracic sternite 3 in $G$. takuan and G. tali being 1.0 times and 1.2 times the length of sternites 1 and 2, respectively, which are shorter than the ratio 2.2 times in G. boreas.

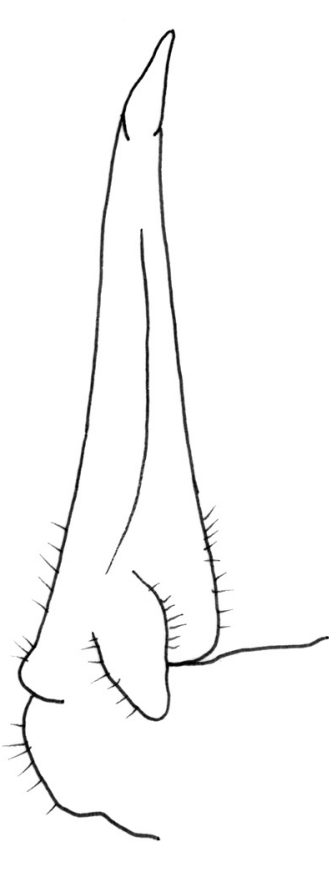

A

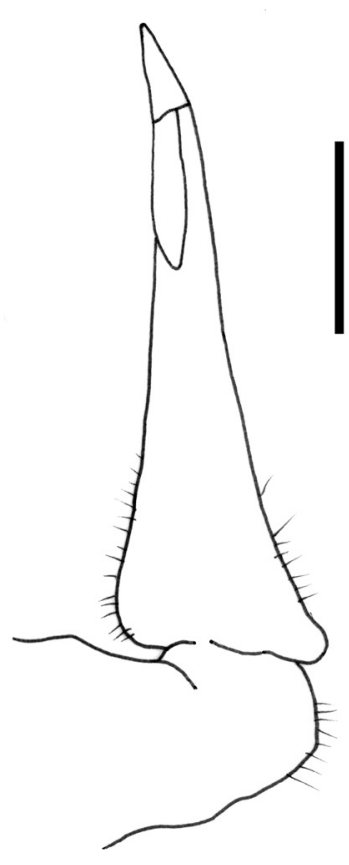

B
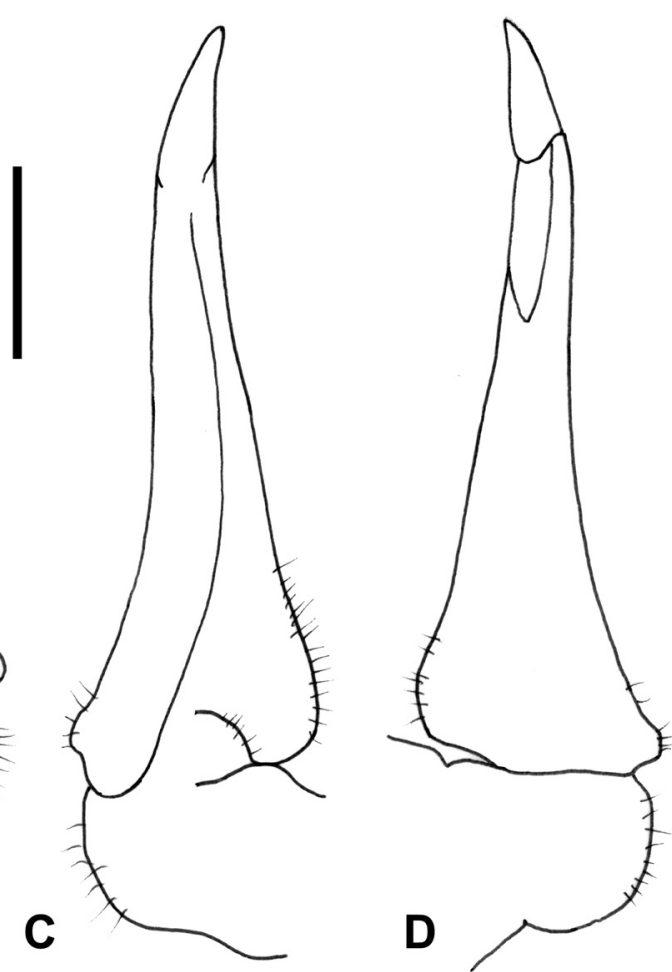

FIGURE 4. Male right G1s of Geothelphusa takuan Shy, Yu \& Ng, 1994 (holotype, NTOU F10205; A, B) and G. hirsuta Tan \& Liu, 1998 (holotype, TMCD 3285; C, D). A, C, ventral view; B, D, dorsal view. Scale = 1 mm.

\section{Geothelphusa takuan Shy, Ng \& Yu, 1994}

(Fig. 4)

Geothelphusa takuan Shy, Ng \& Yu, 1994: 823, fig. 20a-f [type locality: Daguan, Fusing, Taoyuan]; Dai 1999: 387; Shy \& Yu 1999: 75, 2 un-numbered figs.; Ng et al. 2001: 51; Chen et al. 2007a: 881, fig. 8A1-A3; Chen et al. 2007b: 906, fig. 4B; Shy \& Lee 2009: 184, 8 un-numbered figs.; Shih et al. 2011: 461; Ng et al. 2017: 81; Shy et al. 2020: 154, figs. 119-121.

Geothelphusa hirsuta Tan \& Liu, 1998: 288, fig. 2A-E [type locality: Tai-an, Miaoli County, Taiwan]; Ng et al. 2001: 50; Shy \& Lee 2009: 137, 7 un-numbered figs.; Shih et al. 2011: 461; Ng et al. 2017: 79; Shy et al. 2020: 82, figs. 66-68.

Material examined. Types: holotype male (NTOU F10205), Daguan (= Takuan), Fusing (= Fuhsing), Taoyuan Co., Taiwan, coll. J.-Y. Shy \& W.-L. Tsay, 1 Nov. 1992. Geothelphusa hirsuta Tan \& Liu, 1998: holotype male (TMCD 3285), 1 paratype male (TMCD 3292), Guanwu (= Kuanwu), Tai-an, Maioli (24³0’17.5”N 121 07'09.9”E), elevation of 2060 m, coll. H.-C. Liu, 13 Nov. 1993. Others: 3 $\widehat{\jmath}$ (12.0-16.2 mm), 3 q q (12.1-15.9 mm) (NCHUZOOL

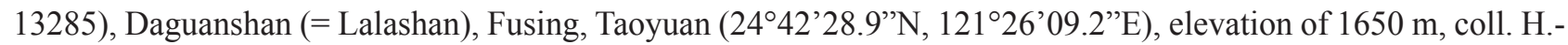

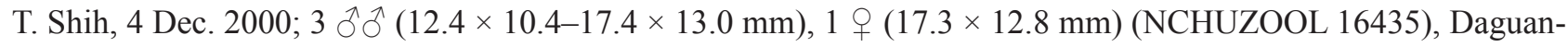

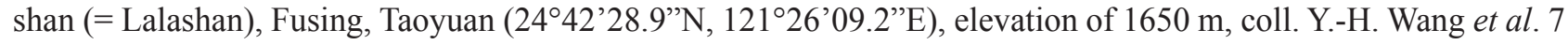


Sep. 2010; 4 ठิ $(13.2 \times 10.8-16.1 \times 12.1 \mathrm{~mm}), 1$ q $(16.2 \times 13.4 \mathrm{~mm})($ NCHUZOOL 17041), Smangus, Jianshih, Hsinchu County $\left(24^{\circ} 34^{\prime} 41.6^{\prime \prime N}, 121^{\circ} 20^{\prime} 47.4^{\prime \prime E}\right)$, elevation of 1560 m, coll. J.-J. Li, 3 Apr. 2021; 3 ô $\widehat{\jmath}(14.8 \times$ 11.6-18.4 × 13.7 mm), 5 우 $(16.5 \times 13.3-20.2 \times 14.9 \mathrm{~mm})($ NCHUZOOL 13432), Syueba Farm, Wufeng, Hsinchu County, coll. 1 Dec. 2001; $1 \widehat{\partial}(18.7 \times 14.3 \mathrm{~mm})($ NCHUZOOL 13431), Sihmasian Forest Road, Tai-an, Miaoli.



FIGURE 5. A Bayesian Inference (BI) tree of Geothelphusa boreas sp. nov. and related montane species from northern Taiwan based on cytochrome oxidase I (COI) marker. Probability values at the nodes represent the support values for BI and maximum evolution (ME). For haplotype abbreviations, see Table 1. Corresponding numbers of localities in Fig. 1 are in parenthesis behind haplotype abbreviations.

Ecological notes: In Daguanshan, Geothelphusa takuan is sympatric with G. ilan. In Smangus, G. takuan is sympatric with G. ilan, G. cilan and G. sp.

Remarks: Based on the figure in Tan \& Liu (1998: fig. 2), the G1 of G. hirsuta with the subterminal segment curves outwards, which is different from the inward curved subterminal segment of G. takuan (Shy et al. 1994). However, after reexamining on the holotype of G. hirsuta (TMCD 3285), we found both the right and left G1s (and G2s) were dissected and stored in small tubes separately. By comparing the right G1 detached from the adult male paratype (TMCD 3292), the labels of left and right on the tubes of holotype are confirmed to be actually reversed. That is, the figure and description for the G1 and G2 in Tan \& Liu (1998) are actually left ones instead. Our reexamination of the right G1s of the holotype (Fig. 4C, D) and paratype of G. hirsuta, found no difference from that of the holotype of G. takuan (NTOU F10205) (Fig. 4A, B). We also find that they differ only in the anterolateral margins, with G. hirsuta having lined with relatively clear granules (Shy et al. 2020: fig. 66) and G. takuan having lined with lower granules (Shy et al. 2020: fig. 119), too small a difference to warrant their recognition as separate taxa. With regard to the genetic similarity for the two species, see "DNA analyses and discussion". Geographically, although the distance between the two type localities of G. takuan (Fig. 1: no. 5) and G. hirsuta (Fig. 1: no. 8) is about $40 \mathrm{~km}$, they belongs to the same mountain range, the Hsuehshan Range (Fig. 1), and a continuous distribution of a single species is expected. 


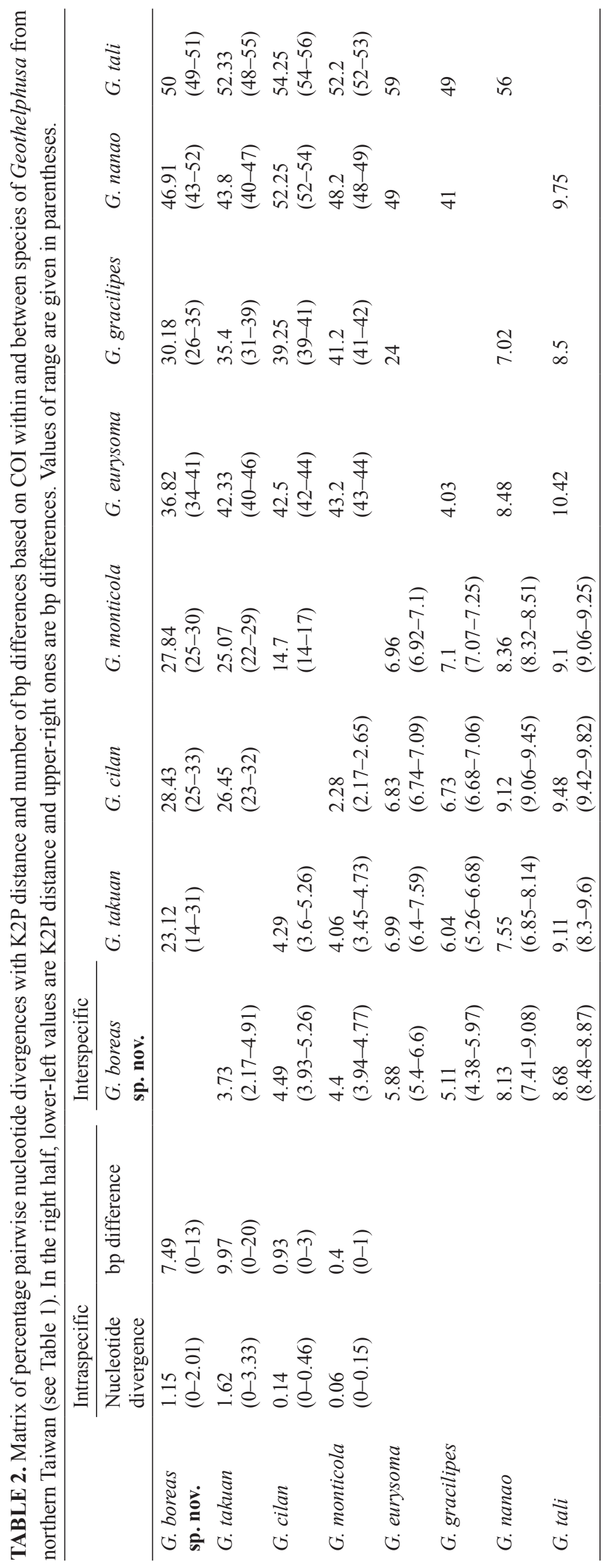




\section{DNA analyses and discussion}

A 616-658 basepair (=bp) segment of COI were amplified and aligned (Table 1). Some paratypes were a bit shorter (616 bp), but otherwise identical to other sequences with $658 \mathrm{bp}$, which omitted from further analyses.

The phylogenetic tree was reconstructed from BI analysis, with the support values from the ME analysis (Fig. 5). It is clear the haplotypes of G. boreas sp. nov. forms an independent clade with strong support, separate from other morphologically similar species. With regard to the clade composed of G. takuan and G. hirsuta (from type specimens; Table 1), specimens from northern area ("5" and " 6 " in Figs. 1, 5) seem different from those from southern area ("8" and "9" in Figs. 1, 5) on the phylogenetic tree (Fig. 5), but another subclade ("Gtk8") from southern area ("7" in Figs. 1, 5) situated in the intermediate position within this clade, which make this clade difficult to be subdivided. The G. monticola clade is sister to the G. cilan clade which form a main clade with strong support.

The pairwise nucleotide divergences for COI with K2P distance and bp differences are shown in Table 2. The mean (and minimum) interspecific K2P distance and bp differences of G. boreas are 3.73\% (and 2.17\%) and 23.12 bp (and 14 bp), with its closest relative, G. takuan. The above minimum interspecific distance is considered small, compared with other freshwater crabs (reviewed by Chu et al. 2015), but is still the same with or larger than some potamids, e.g. $2.17 \%$ between G. cilan and G. monticola (Shy et al. 2014; Table 2); 1.81\% between G. pingtung and G. makatao (Chu et al. 2015). The mean (and highest) intraspecific distance and bp differences of G. boreas are as large as $1.15 \%$ (and 2.01\%) and $7.49 \mathrm{bp}$ (and $13 \mathrm{bp}$ ), and G. takuan also has larger intraspecific distance, 1.62\% (and 3.33\%) and $9.97 \mathrm{bp}$ (and $20 \mathrm{bp}$ ), which could be cause by the wide distributions of the two species (Fig. 1), as in Tiwaripotamon pluviosum Do, Shih \& Huang, 2016, 3.18\% (and 5.25\%) (Do et al. 2016). As a result, we treat $G$. hirsuta Tan \& Liu, 1998 is a junior subjective synonym of G. takuan Shy, Ng \& Yu, 1994, based on the morphological similarity, molecular evidence and the continued distribution.

\section{Acknowledgements}

This study was supported by grants from the National Science Council (NSC 102-2621-B-346-001 and 101-2621B-005-001-MY3), Executive Yuan, Taiwan, to JYS and HTS, respectively; and the Forestry Bureau (98AS-8.5.2FB-e2(1)) and the Luodong Forest District Office, Forestry Bureau (108LRC-09), Council of Agriculture, Executive Yuan, Taiwan, to JJM. Thanks are also due to Jiun-Hong Chen and Chao-Nan Liang (National Taiwan University), and Jheng-Jhang Li (National Sun Yat-sen University), for specimen collection in the Fushan Botanical Garden and Smangus, respectively, Jun-Tsong Lin (TMCD) for helping examine type specimens of G. hirsuta, the members of HTS's laboratory for helping in collection and molecular work, and H. Y. Cheung for improving the manuscript. We would also like to acknowledge reviewer Peter K. L. Ng (National University of Singapore) for greatly improving our manuscript.

\section{References}

Chen, W.-J., Cheng, J.-H., Chen, T.-I. \& Hsu, M.J. (2007a) A comparison of the micromorphology of the G1 of freshwater crabs of the genus Geothelphusa (Brachyura, Potamidae) from Taiwan. Crustaceana, 80, 861-889. https://doi.org/10.1163/156854007781363105

Chen, W.-J., Hsu, M.J. \& Cheng, J.-H. (2007b) A new species of alpine freshwater crab (Brachyura: Potamidae) from Siangyang National Forest Recreation area, Taiwan. Crustaceana, 80, 897-907. https://doi.org/10.1163/156854007781681292

Chu, K.H., Schubart, C.D., Shih, H.-T. \& Tsang, L.M. (2015) Genetic diversity and evolution of Brachyura. In: Castro, P., Davie, P.J.F., Guinot, D., Schram, F.R. \& von Vaupel Klein, J.C. (Eds.), Treatise on Zoology-Anatomy, Taxonomy, Biology-The Crustacea, Complementary to the Volumes Translated from the French of the Traite de Zoologie. 9 (C) (II). Decapoda: Brachyura. Part 2. Brill, Leiden, pp. 775-820. https://doi.org/10.1163/9789004190832_016

Chu, K.-L., Ma, X.-P., Zhang, Z.-W., Wang, P.-F., Lu, L.-N., Zhao, Q. \& Sun, H.-Y. (2018a) A checklist for the classification and distribution of China's freshwater crabs. Biodiversity Science, 26, 274-282. [in Chinese] https://doi.org/10.17520/biods.2018062

Chu, K.-L., Wang, P.-F. \& Sun, H.-Y. (2018b) A new genus and species of primary freshwater crab and a new species of Artopota- 
mon Dai \& Chen, 1985 (Crustacea, Brachyura, Potamidae) from western Yunnan, China. Zootaxa, 4422 (1), $115-131$. https://doi.org/10.11646/zootaxa.4422.1.7

Chu, K.-L., Zhou, L.-J. \& Sun, H.-Y. (2017) A new genus and new species of freshwater crab (Decapoda: Brachyura: Potamidae Ortmann, 1896) from Yunnan Province, China. Zootaxa, 4286 (2), 241-253.

https://doi.org/10.11646/zootaxa.4286.2.7

Dai, A.-Y. (1999) Fauna Sinica. Arthropoda: Crustacea: Malacostraca: Decapoda: Parathelphusidae, Potamidae. Science Press, Beijing, 501 pp., 30 pls. [in Chinese]

Darriba, D., Taboada, G. L., Doallo, R. \& Posada, D. (2012) jModelTest 2: more models, new heuristics and parallel computing. Nature Methods, 9, 772. https://doi.org/10.1038/nmeth.2109

Davie, P.J.F., Guinot, D. \& Ng, P.K.L. (2015) Anatomy and functional morphology of Brachyura. In: Castro, P., Davie, P.J.F., Guinot, D., Schram, F.R. \& von Vaupel Klein, J.C. (Eds.), Treatise on Zoology-Anatomy, Taxonomy, Biology-The Crustacea, complementary to the volumes translated from the French of the Traite de Zoologie. 9(C)(I). Decapoda: Brachyura. Part 1. Brill, Leiden, pp. 11-163. https://doi.org/10.1163/9789004190832_004

Do, V. T., Shih, H.-T. \& Huang, C. (2016) A new species of freshwater crab of the genus Tiwaripotamon Bott, 1970 (Crustacea, Brachyura, Potamidae) from northern Vietnam and southern China. Raffles Bulletin of Zoology, 64, 213-219.

Folmer, O., Black, M., Hoeh, W., Lutz, R. \& Vrijenhoek, R. (1994) DNA primers for amplification of mitochondrial cytochrome c oxidase subunit I from diverse metazoan invertebrates. Molecular Marine Biology and Biotechnology, 3, $294-299$.

Huang, C. (2018) Revision of Yarepotamon Dai \& Türkay, 1997 (Brachyura: Potamidae), freshwater crabs endemic to southern China, with descriptions of two new genera and four new species. Journal of Crustacean Biology, 38, $173-189$. https://doi.org/10.1093/jcbiol/rux120

Huang, C., Ahyong, S.T. \& Shih, H.-T. (2017a) Cantopotamon: a new genus of freshwater crabs from Guangdong, China, with descriptions of four new species (Crustacea: Decapoda: Brachyura: Potamidae). Zoological Studies, 56, 41. https://doi.org/10.6620/ZS.2017.56-41

Huang, C., Ahyong, S.T. \& Shih, H.-T. (2020a) The second known stygomorphic freshwater crab from China, Phasmon typhlops gen. nov. et sp. nov. (Crustacea, Decapoda, Potamidae), diverged at the beginning of the Late Miocene. ZooKeys, 1008, $1-15$. https://doi.org/10.3897/zookeys.1008.58854

Huang, C., Huang, S.-Z. \& Shen, Z.-X. (2020b) A new long-legged terrestrial freshwater crab, Calcipotamon puglabrum gen. nov. et sp. nov. (Crustacea: Decapoda: Potamidae), from Hainan Island, China. Zootaxa, 4766 (3), 447-456. https://doi.org/10.11646/zootaxa.4766.3.4

Huang, C., Mao, S.-Y. \& Huang, J.R. (2014) Two new potamid crabs, Yuexipotamon arcophallus new genus, new species and Minutomon shanweiense new genus, new species, (Crustacea: Decapoda: Brachyura: Potamidae) from southern China. Zootaxa, 3764 (4), 455-466. https://doi.org/10.11646/zootaxa.3764.4.5

Huang, C., Shih, H.-T. \& Ahyong, S.T. (2018) Two new genera and two new species of narrow-range freshwater crabs from Guangdong, China (Decapoda: Brachyura: Potamidae). Journal of Crustacean Biology, 38, 614-624. https://doi.org/10.1093/jcbiol/ruy050

Huang, C., Shih, H.-T. \& Mao, S.-Y. (2016) Yuebeipotamon calciatile, a new genus and new species of freshwater crab from southern China (Crustacea, Decapoda, Brachyura, Potamidae). ZooKeys, 615, 61-72. https://doi.org/10.3897/zookeys.615.9964

Huang, C., Shih, H.-T. \& Ng, P.K.L. (2017b) A new genus and new species of Potamidae (Crustacea: Decapoda: Brachyura: Potamoidea), the first stygomorphic cave crab known from China and East Asia. Zootaxa, 4232 (1), 71-84 + 4250+600. https://doi.org/10.11646/zootaxa.4232.1.5

Huang, C., Wang, J. \& Shih, H.-T. (2020c) A new genus and two new species of freshwater crab (Crustacea: Brachyura: Potamidae) with unusual coiled tip of male second gonopods from Yunnan, southwestern China. Zoological Studies, 59, 24. https://doi.org/10.6620/ZS.2020.59-24

Kimura, M. (1980) A simple method for estimating evolutionary rates of base substitutions through comparative studies of nucleotide sequences. Journal of Molecular Evolution, 16, 111-120. https://doi.org/10.1007/BF01731581

Kumar, S., Stecher, G., Li, M., Knyaz, C. \& Tamura, K. (2018) MEGA X: Molecular Evolutionary Genetics Analysis across computing platforms. Molecular Biology and Evolution, 35, 1547-1549. https://doi.org/10.1093/molbev/msy096

Lanfear, R., Frandsen, P.B., Wright, A.M., Senfeld, T. \& Calcott, B. (2017) PartitionFinder 2: new methods for selecting partitioned models of evolution for molecular and morphological phylogenetic analyses. Molecular Biology and Evolution, 34, 772-773. https://doi.org/10.1093/molbev/msw260

Mao, S.-Y. \& Huang, C. (2020) Descriptions of a new species of Minpotamon Dai \& Türkay, 1997, and a monotypic new genus of aquatic freshwater crab (Brachyura, Potamidae) from eastern Guangdong, China. Crustaceana, 93, 1295-1313. 
https://doi.org/10.1163/15685403-bja10060

Ng, P.K.L. (1988) The Freshwater Crabs of Peninsular Malaysia and Singapore. Shing Lee, Singapore, 156 pp.

Ng, P.K.L., Guinot, D. \& Davie, P.J.F. (2008) Systema Brachyurorum: Part 1. An annotated checklist of extant brachyuran crabs of the world. Raffles Bulletin of Zoology, Supplement 17, 1-296.

Ng, P.K.L., Shih, H.-T., Ho, P.-H. \& Wang, C.-H. (2017) An updated annotated checklist of brachyuran crabs from Taiwan (Crustacea: Decapoda). Journal of the National Taiwan Museum, 70 (3/4), 1-208. https://doi.org/10.6532/JNTM.201712_70(3;4).01

Ng, P.K.L., Shih, H.-T., Naruse, T. \& Shy, J.-Y. (2010) Using molecular tools to establish the type locality and distribution of the endemic Taiwanese freshwater crab Geothelphusa chiui Minei, 1974, (Crustacea: Brachyura: Potamidae), with notes on the genetic diversity of Geothelphusa from eastern Taiwan. Zoological Studies, 49, 544-555.

Ng, P.K.L., Wang, C.-H., Ho, P.-H. \& Shih, H.-T. (2001) An annotated checklist of brachyuran crabs from Taiwan (Crustacea: Decapoda). National Taiwan Museum Special Publication Series, 11, 1-86.

Ortmann, A.E. (1896) Das System der Decapoden-Krebse. Zoologische Jahrbücher, Abtheilung für Systematik, Geographie und Biologie der Thiere, 9 (3), 409-453.

Roman, J. \& Palumbi, S.R. (2004) A global invader at home: population structure of the green crab, Carcinus maenas, in Europe. Molecular Ecology, 13, 2891-2898.

https://doi.org/10.1111/j.1365-294X.2004.02255.x

Ronquist, F., Huelsenbeck, J.P., Teslenko, M. \& Nylander, A.A. (2020) MrBayes 3.2 Manual: Tutorials and Model Summaries. Available from: http://mrbayes.csit.fsu.edu/manual.php (accessed 16 January 2021)

Ronquist, F., Teslenko, M., van der Mark, P., Ayres, D.L., Darling, A., Höhna, S., Larget, B., Liu, L., Suchard, M.A. \& Huelsenbeck, J.P. (2012) MRBAYES 3.2: efficient Bayesian phylogenetic inference and model choice across a large model space. Systematic Biology, 61, 539-542. https://doi.org/10.1093/sysbio/sys029

Schubart, C.D. (2009) Mitochondrial DNA and decapod phylogenies: the importance of pseudogenes and primer optimization. In: Martin, J.W., Crandall, K.A. \& Felder, D.L. (Eds.), Decapod Crustacean Phylogenetics. Crustacean Issues. Vol. 18. CRC Press, Taylor \& Francis Group, Boca Raton, London, New York, pp. 47-65. https://doi.org/10.1201/9781420092592-c4

Shih, H.-T. \& Ng, P.K.L. (2011) Diversity and biogeography of freshwater crabs (Crustacea: Brachyura: Potamidae, Gecarcinucidae) from East Asia. Systematics and Biodiversity, 9, 1-16. https://doi.org/10.1080/14772000.2011.554457

Shih, H.-T., Ng, P.K.L., Naruse, T., Shokita, S. \& Liu, M.-Y. (2011) Pleistocene speciation of freshwater crabs (Crustacea: Potamidae: Geothelphusa) from northern Taiwan and southern Ryukyus, as revealed by phylogenetic relationships. Zoologischer Anzeiger, 250, 457-471. https://doi.org/10.1016/j.jcz.2011.07.004

Shih, H.-T., Shy, J.-Y., Lee, J.-H. (2010) A new freshwater crab of the genus Geothelphusa (Brachyura, Potamidae) from southwestern Taiwan. Crustaceana Monographs, 14, 661-675. https://doi.org/10.1163/9789047427759_048

Shy, J.-Y. \& Lee, P.-W. (2009) Guide to the Taiwanese Freshwater Crabs. Morning Star Publishing, Taipei, 221 pp. [in Chinese]

Shy, J.-Y., Ng, P.K.L. \& Yu, H.-P. (1994) Crabs of the genus Geothelphusa Stimpson, 1858 (Crustacea: Decapoda: Brachyura: Potamidae) from Taiwan, with descriptions of 25 new species. Raffles Bulletin of Zoology, 42, 781-846.

Shy, J.-Y., Shih, H.-T. \& Mao, J.-J. (2014) Description of a new montane freshwater crab (Crustacea: Potamidae: Geothelphusa) from northern Taiwan. Zootaxa, 3869 (5), 565-572. https://doi.org/10.11646/zootaxa.3869.5.6

Shy, J.-Y., Shih, H.-T. \& Ng, P.K.L. (2020) Crustacean Fauna of Taiwan: Brachyuran Crabs. Vol. III. Freshwater CrabsPotamidae, Gecarcinucidae. National Penghu University of Science and Technology, Penghu, $26+232 \mathrm{pp}$.

Shy, J.-Y. \& Yu, H.-P. (1999) Freshwater Crabs of Taiwan. National Museum of Marine Biology/Aquarium, Pingtung, ii + 114 pp. [in Chinese]

Stimpson W (1858) Prodromus descriptionis animalium evertebratorum, quae in Expeditione ad Oceanum Pacificum Septentrionalem, a Republica Federata missa, Cadwaladaro Ringgold et Johanne Rodgers Ducibus, observavit et descripsit.Pars V. Crustacea Ocypodoidea. Proceedings of the Academy of Natural Sciences of Philadelphia, 10, 93-110. https://doi.org/10.5962/bhl.title.51447

Suzuki, H. \& Kawai, T. (2011) Two new freshwater crabs of the genus Geothelphusa Stimpson, 1858 (Crustacea: Decapoda: Brachyura: Potamidae) from islands of southern Kyushu, Japan. Crustacean Research, 40, 21-31. https://doi.org/10.18353/crustacea.40.0_21

Tan, S.H. \& Liu, H.-C. (1998) Two new species of Geothelphusa (Decapoda: Brachyura: Potamidae) from Taiwan. Zoological Studies, 37, 286-290.

Wang, P.-F., Zhang, Z.-W. \& Sun, H.-Y. (2020) Ruiyupotamon, a new genus and four new species of freshwater crabs from northwestern Yunnan, China (Decapoda, Brachyura, Potamidae). Crustaceana, 93, 1315-1342. https://doi.org/10.1163/15685403-bja10059 